\title{
Prevalence and epidemiological profile of Hepatitis B in pregnant women: a population study in a Brazilian Western Amazon city from 2007 to 2015
}

\author{
Marina Cordeiro Gomes Sanson 1 \\ Helena Albuquerque Catão Feitoza 2 \\ Valeria Saraceni 3 \\ Rosalina Jorge Koifman 4 \\ Andrea Ramos da Silva Bessa 5
}

1,2,5 Universidade Federal do Acre. Rodovia BR 364, Km 04, s.n. Distrito Industrial. Rio Branco, AC, Brasil. CEP: 69.920-900. E-mail: m.cordeirogomes@hotmail.com
3 Secretaria Municipal de Saúde. Rio de Janeiro, RJ, Brasil.
4 Escola Nacional de Saúde Pública. Fundação Oswaldo Cruz. Rio de Janeiro, RJ, Brasil.

\begin{abstract}
Objectives: this study aimed to describe the epidemiological profile and prevalence of hepatitis B infection in pregnant women living in Rio Branco, Acre, Brazil.

Methods: this was a cross-sectional study concerning the prevalence of Hepatitis $B$ in a cohort of women who gave birth in Rio Branco from 2007 to 2015. Data were obtained through health information systems. Pregnant women presenting one or more serological markers or positive molecular biology examination were considered confirmed cases of infections. Infection prevalence, the odds ratio (5\% significance) and sociodemographic, clinical, obstetric and neonatal variable frequency distributions were calculated. The student's t-test and Mann Whitney test were applied, as well as the chi-square test or Fisher's exact test, at a significance level of $5 \%$.

Results: a total of 62,100 pregnant women were identified for the study period. The prevalence of Hepatitis B in the group was of 0.38\% (206 cases), and only 12,5\% were diagnosed during the first gestation trimester. A significant difference $(p=0.034)$ in the mean age of infected women was observed when compared to those without infection. The chance of an infected pregnant woman giving birth to a child with a 1st Apgar minute $<7$ was of 2.01 $(C 195 \%=1.09-3.71 ; p=0.995)$, higher than observed for healthy pregnant woman. Concerning infected patients, the most reported risk exposure was dental treatment (19.2\%).

Conclusions: the prevalence of Hepatitis B among pregnant women was lower than reported in other national studies. Low Hepatitis $B$ detection during the first gestation trimester was identified, which reinforces the need to intensify early diagnosis during prenatal follow-up, especially due to the severity of the disease and the possibility of vertical transmission.
\end{abstract}

Key words Health profile, Pregnancy, Hepatitis, Disease notification 


\section{Introduction}

According to the World Health Organization (WHO), hepatitis is one of the most serious and prevalent infectious diseases worldwide. Despite this, it is still neglected by both health services and carriers. Approximately one million deaths worldwide are attributed to viral hepatitis, and estimates indicate about 257 million people worldwide are hepatitis B carriers. ${ }^{1}$

According to the 2017 Epidemiological Bulletin of Viral Hepatitis in Brazil, the age groups presenting the highest number of hepatitis $\mathrm{B}$ cases per 100,000 inhabitants are those ranging from 45 to 49 (12.6), 50 to 54 (11.8), 35 to 99 (11.4) and 40 to 44 years old (11.3). When stratified by gender, hepatitis B prevalence among women was higher in the age group ranging from 25 to 39 years old. 2 This draws attention to the fact that this age group comprises women of reproductive age and, thus, subject to becoming pregnant.

Hepatitis B infection in pregnant women implies the possibility of virus transmission to newborns. The repercussions if they are infected are significant, owing to the high proportion of disease chronicity, due to the immaturity of newborn immune systems. ${ }^{3}$ Ninety percent of those infected can progress to chronicity, most having contracted the infection during delivery, with no scientific evidence of cesarean section referral. Active immunization with the hepatitis $\mathrm{B}$ vaccine and passive immunoglobulin immunization in the first $24 \mathrm{~h}$ of birth of newborns born from HBsAg-positive mothers reduce the risk of infection by over $90 \% .4$ In this sense, the WHO recommends a serological test for hepatitis B screening during pregnancy, availability of accessible and reliable diagnostic tests and the existence of effective prevention and treatment methods for pregnant women diagnosed as positive. 3

In addition, $\mathrm{HBs} \mathrm{Ag}$ marker assessments during prenatal care are recommended in Brazil. This serology should be offered during the first prenatal consultation (regardless of gestational age) and during the third gestation trimester. 5

Due to the aforementioned context, the state of Acre and its capital, Rio Branco, deserve special attention, as they presented the highest Hepatitis B detection rate among Brazilian federative units (40.3/100,000 inhabitants), as well as between capitals $\left(26.3 / 100,000\right.$ inhabitants), in $2016.2^{2}$ On the other hand, vaccine coverage for hepatitis B in Acre increased from $11.2 \%$ in 1994 to $97.6 \%$ in 2009 , closing 2015 at $82.6 \%$. 6

In this context, this study aimed to describe the prevalence and epidemiological profile of confirmed hepatitis B cases in a cohort of pregnant women in the city of Rio Branco, Acre, between 2007 and 2015 , using data available from information systems.

\section{Methods}

A cross-sectional study was carried out in a cohort of pregnant women who delivered both live births and stillbirths in Rio Branco, from 2007 to 2015. Data sources for the cohort establishment were obtained from the following health information systems: Live Birth Information System (Sistema de Informações sobre Nascidos Vivos - SINASC) (pregnant women delivering live births) and Mortality Information System (Sistema de Informação sobre Mortalidade - SIM) (pregnant women giving delivering stillbirths). Data from the Disease Notification Information System (Sistema de Informação de Agravos de Notificação - SINAN) were used concerning pregnant women infected with the hepatitis B virus (HBV).

Hepatitis B was confirmed when pregnant women presented one or more reactive serological markers (reactive $\mathrm{HbsAg}$, reactive anti-HBc IgM or reactive $\mathrm{Hbe} \mathrm{Ag}$ ) or positive molecular biology examination for hepatitis B (detectable HBV DNA). ${ }^{2}$

The independent variables obtained from the information systems were: maternal sociodemographic characteristics (mother age, education level, marital status and skin color); clinical characteristics (gestational trimester of notification, probable source/mechanism of infection, clinical form, previous vaccination and assessed immunological markers); obstetric characteristics (number of prenatal visits, gestational trimester in which prenatal care began, type of delivery, children born alive and deceased in previous pregnancies, gestational trimester of notification, gestational age at birth, place of birth and type of gestation) and neonatal characteristics (gender, birth weight, Apgar score at 1 and 5 minutes and presence of congenital malformations).

All pregnant women living in the municipality of Rio Branco from 2007 to 2015 were included in the study. After the cohort establishment, hepatitis B cases during the study period were identified using the SINAN database. SIM and SINASC database searches for 2016 were carried out to detect the outcomes of women reported at the end of 2015.

The variables contained in the SINAN (hepatitis), SIM (fetal death) and SINASC databases concerning Rio Branco residents (women who gave birth in the city but came from other municipalities, 
were excluded) were cleaned up and standardized using STATA version 11.0 statistical package. The probabilistic linkage of databases was performed using the OpenRecLink software (ORL).

The first relationship was carried out between SINAN database (containing information from the reported women) and fetal SIM. The variables for the probabilistic linkage relationship (ORL) were: pregnant woman's name, mother's name, mother's age, pregnant woman's age, year of notification, year of death and neighborhood (for visual inspection). Subsequently, blocking was performed, using first and last names. The parameters for the pregnant woman's name variable for probabilistic relationship were: Approximate type, Correct "92", Incorrect "1" and Threshold "85", according to the Reclink III Manual.

The second base relationship was carried out between the SINAN and SINASC databases. The variables for the probabilistic linkage relationship (ORL) were: pregnant woman;s name or mother;s name, mother's name, date of birth and city of residence (for visual inspection). Subsequently, blocking performed in two steps: initially using the first name, last name and mother's age, and then blocking by first and last names. The parameters for the relationship of mother's name variable were: Approximate type, Correct "92", Incorrect "1" and Threshold "85", and for the mother age variable: type "Character", Correct "90", Incorrect "5" and Threshold "65", according to the Reclink III Manual.

Data were analyzed using Statistical Package for Social Sciences (SPSS) software, version 24.0. Absolute and relative frequency measurements and central tendency measures for each of the continuous variables were calculated. The Student's t test and the Mann Whitney "U" test were used to compare continuous variable distributions. For categorical variables, a simple proportion was used, with values expressed as percentages. The chi-square or exact Fischer test were applied, at a significance level of $5 \%$, for proportion comparisons.

The frequency measure of the prevalence type was calculated to estimate the prevalence of hepatitis $\mathrm{B}$ among pregnant women. Factors associated with hepatitis B infection were considered as association measures of the odds ratio at $95 \%$ confidence intervals.

Infection prevalence trend over time was assessed by a simple linear regression. The study was approved by the Hospital das Clínicas do Acre Research Ethics Committee (Protocol No. 1.899.737)

\section{Results}

A total of 254 hepatitis B cases were reported in the SINAN database, with laboratorial confirmation during the study period. A total of 13 women did not reside in the city of Rio Branco (detected through the use of their residence city code), and were excluded from the analysis. Two duplicity cases in the database were also noted. Thus, a total of 239 reports of pregnant women infected with hepatitis B virus were obtained (Figure 1).

The city of Rio Branco presented a cohort of 62,100 resident pregnant women who delivered live births $(61,605)$ and stillbirths $(495)$ in the study period. After the probabilistic linkage of SINAN databases with SINASC and SIM databases, 203 occurrences were found in the SINASC database, reduced to 206 final records due to twinning. The cohort also included two births in 2016, whose mothers were reported as infected in 2015. No cases were identified in the SIM database. Data on 36 pregnant women were not found in any of the investigated databases (Figure 1)

The prevalence of hepatitis B in the group of pregnant women from 2007 to 2009 presented a small decreasing fluctuation. However, from 2010 onwards, an increasing prevalence trend was observed, with the highest measure among the nine studied years $(0.55 \%)$ detected in 2011. From 2012 to 2014 , infection prevalence tended to remain stable, with only one increase noted for 2013. The lowest prevalence was observed in the last study year (2015) $(0.25 \%)$. The total prevalence of the investigated period was of $0.38 \%$. No significant decreasing prevalence trend between 2011 and 2015 was noted ( $p=0.359)$ (Figure 2 ).

The mean age of infected women (25.8 years) was significantly higher than uninfected women (24.9 years) $(p=0.034)$. Concerning marital status, infection prevalence in pregnant women was similar between women with partners $(0.3 \%)$ and those without $(0.3 \%)$, while women with lower education levels displayed higher infection prevalence, albeit with no statistical difference $(p=0.713)$ (Table 1$)$.

Using the baseline prenatal follow-up in the third gestation trimester, the odds of being a hepatitis B virus carrier were 2.11 -fold $(\mathrm{CI} 95 \%=0.77-5.80)$ higher in those who began prenatal follow-up during the first trimester and 2.43-fold (CI95\%=0.86-6.81) in those who began prenatal follow-up during the second trimester. No significant difference concerning type of delivery between groups was observed $(p=0.402)$, although most infected women underwent normal labor. One hundred and ninety 
Figure 1

Data relationship scheme of confirmed pregnant women with hepatitis B in the SINAN, SINASC and SIM databases, in the municipality of Rio Branco, Brazil, from 2007 to 2015.

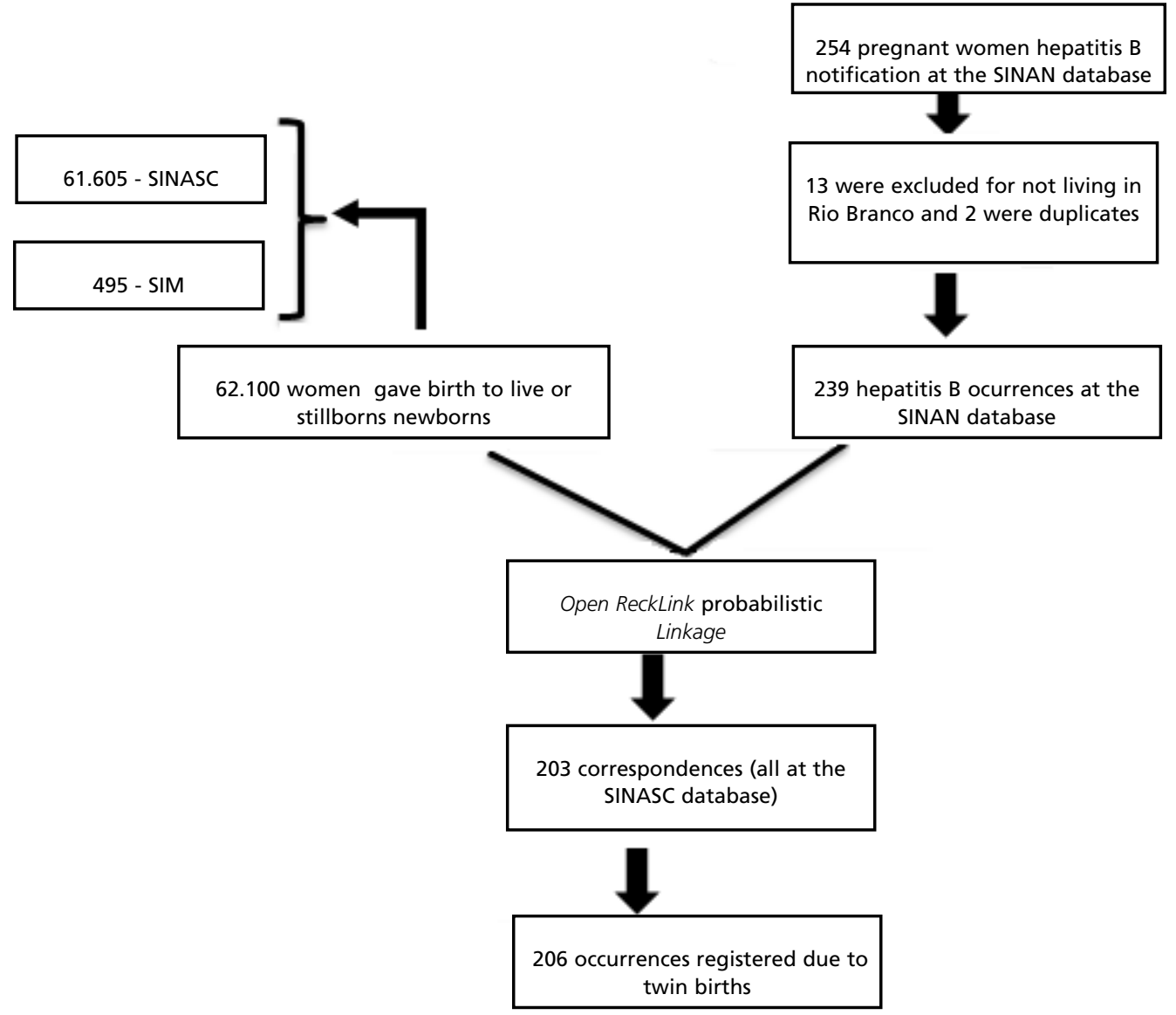

Source: SINAN, SINASC and SIM (2017).

Figure 2

Prevalence of Hepatitis B in pregnant women living in Rio Branco, Acre, from 2007 to 2015.

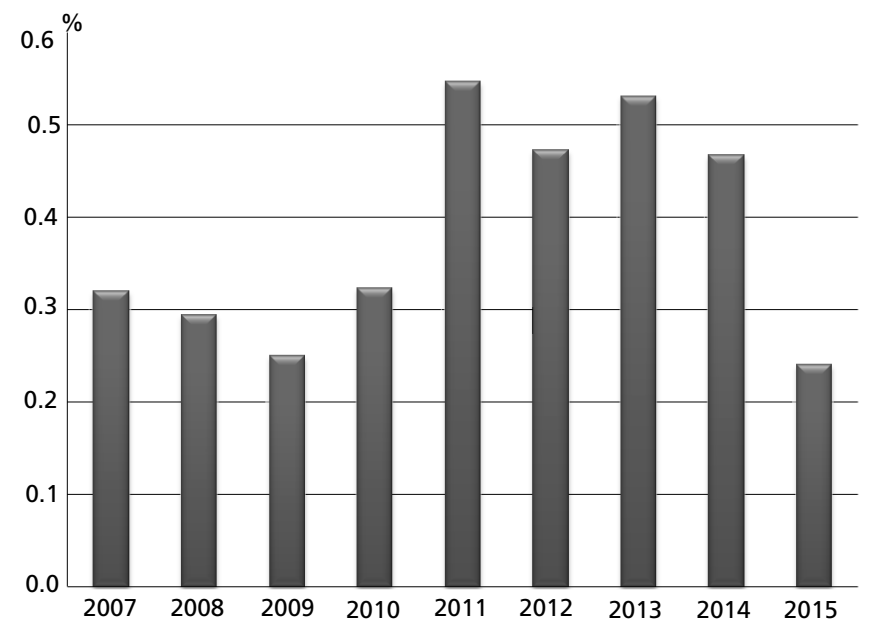

Source: SINAN, SEMSA - Rio Branco, AC. 
Frequency distribution and odds ratio according to maternal, obstetric and neonatal characteristics of pregnant women with HBV according to the SINASC (Live Birth Information System) database, in the city of Rio Branco, Acre, from 2007 to 2015.

\begin{tabular}{|c|c|c|c|c|c|c|}
\hline \multirow[t]{3}{*}{ Variable } & \multicolumn{4}{|c|}{ HBV carrier } & \multirow{3}{*}{ OR (C195\%) } & \multirow[t]{3}{*}{$p$} \\
\hline & \multicolumn{2}{|c|}{ No $(61,896)$} & \multicolumn{2}{|c|}{ Yes (206) } & & \\
\hline & $\mathrm{n}$ & $\%$ & $\mathrm{n}$ & $\%$ & & \\
\hline Mother age* (years) & & & & & & 0.128 \\
\hline$<25$ & 31,834 & 99.7 & 95 & 0.3 & 1 & \\
\hline$>25$ & 30,020 & 99.6 & 111 & 0.4 & $1.23(0.94-1.63)$ & \\
\hline Marital status* & & & & & & 0.986 \\
\hline With partner & 48,197 & 99.7 & 162 & 0.3 & 1 & \\
\hline Without partner & 12,457 & 99.7 & 42 & 0.3 & $1.00(0.71-1.40)$ & \\
\hline Mother schooling* (years) & & & & & & 0.713 \\
\hline$>8$ & 49,815 & 99.7 & 165 & 0.3 & 1 & \\
\hline$<8$ & 11,027 & 99.6 & 39 & 0.4 & $1.07(0.75-1.51)$ & \\
\hline Number of prenatal consultations & & & & & & 0.156 \\
\hline$<6$ & 60,669 & 99.7 & 205 & 0.3 & $4.15(0.58-29.60)$ & \\
\hline$>6$ & 1,227 & 99.9 & 1 & 0.1 & 1 & \\
\hline Type of delivery* & & & & & & 0.402 \\
\hline Vaginal & 34,685 & 99.6 & 122 & 0.4 & 1 & \\
\hline Cesarean & 26,900 & 99.7 & 84 & 0.3 & $0.89(0.67-1.17)$ & \\
\hline Place of birth * & & & & & & 0.738 \\
\hline Hospital & 61,676 & 99.7 & 205 & 0.3 & 1 & \\
\hline Other & 215 & 99.5) & 1 & 0.5 & $1.40(0.19-10.03)$ & \\
\hline Newborn sex * & & & & & & 0.605 \\
\hline Female & 30,194 & 99.7 & 97 & 0.3 & 1 & \\
\hline Male & 31,686 & 99.7 & 109 & 0.3 & $0.93(0.71-1.22)$ & \\
\hline Congenital anomaly detected ** & & & & & & 0.085 \\
\hline Yes & 189 & 99.0 & 2 & 1.0 & $3.42(0.84-13.90)$ & \\
\hline No & 51,735 & 99.7 & 160 & 0.3 & 1 & \\
\hline Low weight at birth * & & & & & & 0.597 \\
\hline Yes & 5,449 & 99.7 & 16 & 0.3 & $0.87(0.52-1.45)$ & \\
\hline No & 56,075 & 99.7 & 189 & 0.3 & 1 & \\
\hline 1st minute Apgar ** & & & & & & 0.995 \\
\hline 0 to 6 & 1,723 & 99.4 & 11 & 0.6 & $2.01(1.09-3.71)$ & \\
\hline 7 to 10 & 50,396 & 99.7 & 160 & 0.3 & 1 & \\
\hline $5^{\text {th }}$ minute Apgar ** & & & & & & 0.995 \\
\hline 0 to 6 & 290 & 100.0 & 0 & - & 0.00 & \\
\hline 7 to 10 & 51,827 & 99.7 & 171 & 0.3 & & \\
\hline
\end{tabular}

* no information $<5 \%$; ** no information $10-20 \%$; HBV $=$ hepatitis $B$ virus.

Source: SINASC, SEMSA - Rio Branco, AC.

congenital anomaly cases were identified in the cohort. Of these, $1 \%$ occurred in children born from infected women. The chance of a woman with hepatitis giving birth to a child presenting a congenital anomaly was 3.42 -fold $($ CI95\% $=0.84-13.90)$ higher than the chance of a non-carrier pregnant woman (Table 1).

The mean weight of newborns in the cohort was of 3,199.04 grams, while newborns from the virus carrier group presented mean weight of $3,240.37$ grams, a non-significant difference $(p=0.201)$. Among low birth weight cases $(<2,500 \mathrm{~g}), 0.3 \%$ were from mothers diagnosed positive for hepatitis B. The chance of a woman with hepatitis B birthing a child with 1st Apgar $<7$ was 2.01-fold (CI95\%= 1.09-3.71) higher than a healthy woman. No signifi- 
cant difference was observed for the $5^{\text {th }}$ minute Apgar $(p=0.995)$. The variables maternal race, the period in which they began prenatal care and gestational age at the time of delivery were also contained in the SINASC database, but were excluded from the analyses, as they presented over $50 \%$ castels without information (Table 1).

Most (43.1\%) of notifications occurred in the third gestation trimester. Only $20.6 \%$ of the pregnant women reported had undergone the complete hepatitis B vaccine regimen and $59.4 \%$ had not been previously vaccinated. The main marker used for diagnosis was HBsAg, positive for all infected women. Anti-HBc Igm, which indicates recent contact with the virus, was positive in $1.3 \%$ of the pregnant women, while $\mathrm{HBeAg}$, indicator of viral replication, was reactive in $7.9 \%$ of the pregnant women.

The anti-HBs marker, which indicates immunity to the hepatitis virus, by previous contact or vaccina- tion, was not assessed in $74.5 \%$ of the women, and was reactive in only $0.8 \%$. All women presented hepatitis B diagnosis through laboratory confirmation. A total of $98.7 \%$ of the subjects were chronic or asymptomatic carriers. It is also important to highlight that $9.2 \%$ of the pregnant women reported presented associated hepatitis Delta (Table 2). Among the subjects, $10.3 \%$ reported having had sexual contact with virus carriers for less than six months, and $11.7 \%$ reported home contact for over than six months. Seven women $(3.9 \%)$ reported occupational contact with the virus for over six months, $18.4 \%$ reported exposure to injectable medications and $14.3 \%$ reported having been undergone tattooing or piercing. Dental treatment $(21.7 \%)$ was also reported, and $9.5 \%$ of the subjects reported having had three or more sexual partners for over six months. None of the pregnant women reported having undergone acupuncture, blood transfusion, drug injections or transplantation (Table 3).

\section{Table 2}

\begin{tabular}{|c|c|c|}
\hline \multirow[t]{2}{*}{ Variables } & \multicolumn{2}{|c|}{ Hepatitis B } \\
\hline & $\mathrm{N}$ & $\%$ \\
\hline \multicolumn{3}{|c|}{ Gestation trimester notification } \\
\hline 1st trimester & 30 & 12.5 \\
\hline 2nd trimester & 80 & 33.5 \\
\hline 3rd trimester & 103 & 43.1 \\
\hline Ignored gestational age & 26 & 10.9 \\
\hline \multicolumn{3}{|c|}{ Vaccine scheme for hepatitis B } \\
\hline Complete & 37 & 20.6 \\
\hline Incomplete & 36 & 20.0 \\
\hline Not vaccinated & 107 & 59.4 \\
\hline No information & 59 & 24.7 \\
\hline \multicolumn{3}{|l|}{ Anti-HBS } \\
\hline Reactive/Positive & 2 & 0.8 \\
\hline Non-reactive/Negative & 59 & 24.7 \\
\hline Not performed & 178 & 74.5 \\
\hline \multicolumn{3}{|l|}{ HBsAg } \\
\hline Non-reactive/Negative & & - \\
\hline Reactive/Positive & 239 & 100.0 \\
\hline Not performed & 0 & - \\
\hline \multicolumn{3}{|l|}{ HBeAg } \\
\hline Reactive/Positive & 19 & 7.9 \\
\hline Non-reactive/Negative & 152 & 63.6 \\
\hline Not performed & 68 & 28.5 \\
\hline
\end{tabular}

continue HBV = hepatitis B virus; SINAN= Disease Notification Information System (Sistema de Informação de Agravos de Notificação). Source: SINAN, SEMSA - Rio Branco, AC. 
Characteristics of pregnant women infected with HBV, according to SINAN's clinical conditions, in the city of Rio Branco, Acre, from 2007 to 2015.

\begin{tabular}{|c|c|c|}
\hline \multirow[t]{2}{*}{ Variable } & \multicolumn{2}{|c|}{ Hepatitis B } \\
\hline & $\mathrm{N}$ & $\%$ \\
\hline \multicolumn{3}{|l|}{ Anti- HBC Igm } \\
\hline Reactive/Positive & 3 & 1.3 \\
\hline Non-reactive/Negative & 88 & 36.8 \\
\hline Not performed & 148 & 61.9 \\
\hline \multicolumn{3}{|l|}{ Anti-HBc Total } \\
\hline Reactive/Positive & 219 & 91.6 \\
\hline Non-reactive/Negative & 3 & 1.3 \\
\hline Not performed & 17 & 7.1 \\
\hline \multicolumn{3}{|l|}{ Method for final classification } \\
\hline Laboratory Confirmation & 239 & 100.0 \\
\hline \multicolumn{3}{|l|}{ Clinical form } \\
\hline Acute hepatitis & 3 & 1.3 \\
\hline Chronic asymptomatic hepatitis & 236 & 98.7 \\
\hline \multicolumn{3}{|l|}{ Etiological classification } \\
\hline Virus B & 217 & 90.8 \\
\hline Virus $B$ and $D$ & 22 & 9.2 \\
\hline
\end{tabular}

HBV = hepatitis B virus; SINAN= Disease Notification Information System (Sistema de Informação de Agravos de Notificação). Source: SINAN, SEMSA - Rio Branco, AC.

Table 3

Distribution of information on the self-reported probable source of HBV infection among infected pregnant women, according to SINAN data, in the municipality of Rio Branco - Acre, from 2007 to 2015.

\begin{tabular}{|c|c|c|c|c|c|c|c|c|}
\hline \multirow[t]{3}{*}{ Variable } & \multicolumn{5}{|c|}{ Exposure $\mathrm{n}(\%)$} & \multicolumn{3}{|c|}{$\begin{array}{l}\text { Total ( }{ }^{\circ} \text { of reports/ } \\
n^{\circ} \text { infected women) }\end{array}$} \\
\hline & \multicolumn{2}{|c|}{$\begin{array}{l}\text { Yes, less than } \\
6 \text { months ago }\end{array}$} & \multicolumn{2}{|c|}{$\begin{array}{l}\text { Yes, over } 6 \\
\text { months ago }\end{array}$} & \multicolumn{2}{|c|}{ No } & \multirow[t]{2}{*}{$\mathrm{N}$} & \multirow[t]{2}{*}{$\%$} \\
\hline & $\mathrm{n}$ & $\%$ & $\mathrm{n}$ & $\%$ & $\mathrm{n}$ & $\%$ & & \\
\hline \multicolumn{9}{|c|}{ Sexual contact with HBV carriers } \\
\hline No information: 84 (35.1) & 16 & 10.3 & 14 & 9.0 & 125 & 80.7 & 30 & 12.8 \\
\hline \multicolumn{9}{|c|}{ Home contact with HBV carriers } \\
\hline No information: 68 (28.5) & 15 & 8.8 & 20 & 11.7 & 136 & 79.5 & 35 & 15.0 \\
\hline \multicolumn{9}{|c|}{ Occupational Contact with HBV carriers } \\
\hline No information: 61 (25.5) & 0 & - & 7 & 3.9 & 171 & 96.1 & 7 & 3.0 \\
\hline \multicolumn{9}{|l|}{ Exposure to injectable drugs } \\
\hline No information: 27 (11.3) & 24 & 11.3 & 15 & 7.1 & 173 & 81.6 & 39 & 16.7 \\
\hline \multicolumn{9}{|l|}{ Exposure to tattoos/piercings } \\
\hline No information: 27 (11.3) & 9 & 4.3 & 21 & 9.9 & 181 & 85.8 & 30 & 12.8 \\
\hline \multicolumn{9}{|c|}{ Exposure to accident with biological material } \\
\hline No information: 27 (11.3) & 1 & 0.5 & 0 & - & 211 & 99.5 & 1 & 0.4 \\
\hline \multicolumn{9}{|c|}{ Exposure to inhalable drugs or crack } \\
\hline No information: 27 (11.3) & 2 & 0.9 & 0 & - & 210 & 99.1 & 2 & 0.8 \\
\hline \multicolumn{9}{|l|}{ Undergoing surgical treatment } \\
\hline No information: 27 (11.3) & 3 & 1.4 & 20 & 9.4 & 189 & 89.2 & 23 & 9.9 \\
\hline \multicolumn{9}{|l|}{ Undergoing dental treatment } \\
\hline No information: 27 (11.3) & 10 & 4.7 & 36 & 17.0 & 166 & 78.3 & 46 & 19.6 \\
\hline \multicolumn{9}{|c|}{ Exposed to three or more sexual partners } \\
\hline \multirow[t]{2}{*}{ No information: 28 (11.7) } & 1 & 0.5 & 20 & 9.5 & 190 & 90.0 & 21 & 9.0 \\
\hline & & & & & & & 234 & 100.0 \\
\hline
\end{tabular}

HBV = hepatitis B virus; SINAN= Disease Notification Information System (Sistema de Informação de Agravos de Notificação). Source: SINAN, SEMSA - Rio Branco, AC. 


\section{Discussion}

The prevalence of hepatitis B varies geographically and tends to fluctuate within different groups, such as pregnant women. In the present study, carried out in the State of Acre, a $0.38 \%$ hepatitis B prevalence during pregnancy was observed, which follows the national standard, according to other studies carried out in Brazil, of $0.3 \%$ in the State of Mato Grosso do Sul , ${ }^{7} 0.5 \%$ in Paraná, ${ }^{8}$ and $0.7 \%$ in Amazonas. ${ }^{9}$ The prevalence of hepatitis B during pregnancy is higher in an international context, especially in African countries, with a decreasing tendency in Asian and European countries. The prevalence of the virus in pregnant women was of $14.7 \%$ in Uganda, $102.2 \%$ in Indonesia 11 and $0.4 \%$ in Madri, 12 Spain.

In 2011, a significant increase in hepatitis B prevalence was observed herein, sustained in the following years, decreasing in 2015. This data is directly linked to improved access to the exams, caused by the implementation of rapid tests in prenatal care, ${ }^{3}$ which occurred in the State of Acre in 2011.

The findings indicate a higher prevalence $(0.4 \%)$ of the virus in women older than or equal to 25 years old, similar to what was reported in a study carried out using the SIM, SINASC, SIH and SINAN databases for the municipality of Itajaí, in the State of Santa Catarina, where pregnant women were 21 years of age or older in $82.7 \%$ of the investigated cases. 13 This higher seropositivity in an older age group suggests that virus exposure time interferes with contagion. 14

When analyzing marital situation, the prevalence of hepatitis B was the same in groups with and without partners. However, among infected women, most $(79.4 \%)$ had a partner. This is similar to the results from a study carried out in a public maternity hospital in the municipality of Catalão, in the state of Goiás, where the highest prevalence of positive HBsAg $(0.1 \%)$ was observed among married women. ${ }^{15}$ Women in stable unions and driven by the trust and intimacy acquired in their relationship, tend to limit or extinguish the use of condoms. However, in some cases, monogamy is not reciprocal, which may expose this group to different sexually transmitted infections. 16

Regarding maternal schooling, the highest prevalence of hepatitis B was among pregnant women with education equal to or less than eight years of schooling. A similar finding was found in a study carried out with blood donors, also in the State of Acre, where most patients who presented total reactive anti-HBc (a marker used in hepatitis $B$ exposure assessments) had schooling equal to or lower than the complete fundamental level. ${ }^{14}$ Low schooling may act as a barrier to the incorporation of new health practices, either due to difficulty in understanding past information or lack of recognition of their importance. In the case of hepatitis, this directly impacts vaccination and the prevention of risk behaviors.

This is exemplified by the higher prevalence of hepatitis B in the group of women who performed less than six prenatal visits $(0.3 \%)$. The Ministry of Health emphasizes that pregnancy follow-up should comprise at least six consultations, which can be performed by a physician and/or a nurse, ideally beginning in the first gestation trimester. 5 In the present study, the highest infection prevalence was observed in pregnant women who began follow-up in the second trimester $(0.5 \%)$ and the lowest, in the third $(0.2 \%)$.

In a study carried out in Rajkot, India, with 1,038 pregnant women attended in an outpatient clinic, the highest HBsAg prevalence was identified in the second trimester, followed by the first and third trimesters. 17 This scenario was dissimilar to that observed in the present study, where the lowest number of notifications was detected in the first trimester (12.6\%). This is troubling, since, ideally, women should perform and receive the results of their laboratory tests during the first trimester. Early diagnosis provides treatment initiation and provides subsidies for interventions against vertical hepatitis B transmission. Currently, a diagnosis could certainly be made at the first prenatal visit with the use of rapid hepatitis B tests.

Regarding acute HBV infection, it is important to note that higher prematurity rates, low birth weight, and fetal or perinatal death are observed among newborns born from carrier mothers. This, however, may be related to other factors associated to the presence of the virus, such as drug use. ${ }^{4}$

In both the cohort and the carrier group, most deliveries were performed vaginally. These data point to the tendency of good obstetric and newborn care practice and the appreciation of normal birth, taking into account the lack of evidence to justify the performance of elective cesarean sections in order to reduce vertical transmission rates. The recommendation of the Brazilian Ministry of Health is that, to do so, invasive procedures, laborious deliveries and membranes rupture time of over six hours should be avoided. 4

In the carrier group, the highest prevalence of the pathology was observed in mothers of children born with Apgar $<7$ in the first minute of life. A cross- 
sectional study also carried out in the city of Rio Branco, identified maternal and neonatal characteristics in pregnant women with hepatitis B from SINAN, SINASC and SIM data, where a total of $6.8 \%$ of the children, daughters of infected mothers presented first-minute Apgar less than seven. As was observed herein, all patients presented an Apgar index of over seven at the $5^{\text {th }}$ minute. 18

Regarding clinical conditions, over half of the pregnant women $(59.4 \%)$ were not vaccinated against hepatitis B, and among those vaccinated, only $20.6 \%$ had completed the vaccination scheme. This is worrying and controversial, taking into account that the National Immunization Program (PNI) started the vaccination against hepatitis B in the Western Amazon (where Acre is located) in 1989 , due to the high prevalence of the virus. In 1994, the vaccine was offered to professionals from the private sector, firefighters, police, military and medical, dentistry, nursing and biochemistry students. Four years later, in 1998, the vaccine was offered to all children under one year old of the entire national territory. Currently, the vaccine is available in Basic Health Units for all citizens. 19 This reflects the population's lack of knowledge concerning the protection afforded by the hepatitis B vaccine after the complete vaccination schedule.

Hepatitis B can be diagnosed based on clinical data (suspected case) or by screening applying laboratory methods. 20 In the present study, all suspected cases were confirmed by serological tests. The main marker used for diagnosis was HBsAg, which was reactive in all pregnant women, at a prevalence of $0.38 \%$. This marker is the first to appear in acute infections, declining to undetectable levels after 24 weeks. Its presence for a longer period of time indicates chronic condition. ${ }^{20}$ In the state of Amazonas, a cross-sectional study carried out with 1,460 pregnant women in $2000-2001$ found a $4.8 \%$ prevalence of this marker in the Purus River region, which is bordered by the municipality of Rio Branco.21 Another study also carried out in Amazonas with 674 pregnant women reported a prevalence of $0.7 \%$ in the city of Manaus. ${ }^{9}$ In the same study, cases with positive $\mathrm{HBsAg}$ were also assessed for $\mathrm{HBeAg}$, and prevalence was reported as $0.5 \% .{ }^{9}$ This marker reflects viral replication and its presence points to high infectivity. 20 In the present study, HBeAg was positive in $7.9 \%$ of the women who presented reactive HBsAg and was not assessed in $28.5 \%$ of the women.

Failure to perform HbeAg leads to a worrying scenario, considering that maternal prophylactic antiretroviral therapy is indicated in the case of preg- nant women presenting high $\mathrm{HBeAg}$, since, in these situations, newborn care after birth may be not be sufficient for the prevention of perinatal transmission. ${ }^{4}$ In general, not all HBV markers were investigated in suspected cases, pointing to laboratory limitations.

In the state of São Luís do Maranhão, a crosssectional study aimed to identify the prevalence of HBV markers in 541 pregnant women attended at public maternity hospitals in the city. A total of $0.9 \%$ were chronic carriers and total positive anti-HBc was identified in $0.8 \% .22$ This marker refers to prior contact with the $\mathrm{HBV},{ }^{21}$ and was reactive in most of the pregnant women assessed herein (91.6\%).

Anti-HBc IgM is one of the components of total anti $\mathrm{HBc}$, and is detected within 32 weeks after infection, 22 reflecting recent contact. Based on this, it was used to identify patients presenting the acute pathology (1.3\%).20 It would be important for SINAN to investigate when the disease was acquired (before or during pregnancy), as the risk of infection varies according to the pregnancy trimester in which the mother was infected. This risk is higher during the second or third trimesters, over $60 \%$, versus $10 \%$ or less in newborns whose mothers were infected during the first trimester. 4

Regarding the probable mechanism of recent contamination (less than six months) the most reported mechanism herein was the use of injectable medications $(11.3 \%)$. On the other hand, dental treatment was the most reported for late contact (over six months), at $17.0 \%$. Dental treatment remained the most frequent (19.6\%) when comparing different sources of exposure, followed by the use of injectable medications (11.3\%) and home contact $(15.0 \%)$. Exposure to biological material was the least reported $(0.4 \%)$. These findings differ from the national scenario, where the most common sources of infection are sexual contact (53.6\%), household contact $(7.5 \%)$ and vertical transmission $(7.1 \%){ }^{2}$ This difference is possibly the result of the analyzed group, since the source of sexual infection is often associated with male behavioral factors, which were not included in the present study.

The limitations of the present study relate to the quality of the data obtained from the information systems. Some variables presented missing values above $50 \%$, especially in the SINASC database, which compromises the results of the analyses. However, a decrease in data incompleteness after 2011 was noted, when the new SINASC form was implemented. A study carried out in five municipalities in the Juruá Valley region, in the State of Acre, assessed the quality of the information contained in 
the SINASC database, and observed the same increase in data incompleteness over the years, especially concerning pregnancy-related variables. ${ }^{23}$

Another limitation is the lack of information in the SINASC database concerning prenatal exams. Thus, it is not known if the entire cohort was tested for hepatitis B. If the answer were negative, it would mean that the data could be underestimated.

Despite these limitations, this study contributed to the expansion of knowledge on hepatitis B during pregnancy in the Amazon region, since this subject is scarcely discussed in the scientific community. In addition, assessments carried out during a lengthy period of time allowed for a glimpse of the evolution of incidence rates of this disease in the studied group, as well as the assessment of a high number of pregnant women.

\section{Final considerations}

The results indicate that hepatitis B may be associated with certain maternal characteristics, such as age and low schooling, in addition to interfering in neonatal outcomes, such as the first minute Apgar score, which presented a significant association with maternal infection.

In light of the above, it is concluded that Health Information Systems are tools that provide scenarios concerning different situations of interest to public health, thus becoming an important source of evidence for the development, management and mapping of actions, in addition to enabling the evaluation of the effectiveness of actions already implemented. However, for effectiveness, it is necessary to invest in the training of professionals to correctly input the system.

Vaccination is the best prevention for hepatitis B and should undergo annual coverage assessments, since this input is available and intervention is highly cost-effective. The implementation of HBsAg analyses during prenatal care is mandatory in high prevalence places areas, considering that measures to reduce vertical transmission and associated morbidity are available in the country, including quick tests.

\section{References}

1. WHO (World Health Organization). Hepatitis B [Internet] 2018 [acesso em 28 jul 2018]. Disponível em: http://www.who.int/news-room/fact-sheets/detail/hepatitis-

2. Brasil. Boletim Epidemiológico. Hepatites Virais. Brasília, DF: Ministério da Saúde; 2017.

3. Silva CF, Araújo CLF, Araújo MM. Oferta do teste sorológico para hepatite B durante o pré-natal: a vivência das puérperas. Rev Enferm UERJ. 2015; 23 (1): 58-63.

4. Brasil. Protocolo clínico e diretrizes terapêuticas para prevenção da transmissão vertical de HIV, sífilis e hepatites virais. Departamento de DST, Aids e Hepatites Virais, Brasília: Ministério da Saúde; 2015.

5. Brasil. Ministério da Saúde. Atenção ao pré-natal de baixo risco. Brasília, DF; 2012

6. Brasil. Ministério da Saúde. Banco de dados do Sistema Único de Saúde-DATASUS [Internet]. 2018 [acesso 13 Jan 2018]. Disponível em: http://www.datasus.gov.br

7. Figueiró-Filho EA, Senefonte FR de A, Lopes AHA Morais OO de, Souza Júnior VG, Maia TL, et al. Frequência das infecções pelo HIV-1, rubéola, sífilis, toxoplasmose, citomegalovírus, herpes simples, hepatite $\mathrm{B}$, hepatite $\mathrm{C}$, doença de Chagas e HTLV I/II em gestantes, do Estado de Mato Grosso do Sul. Rev Soc Bras Med Trop. 2007; 40 (2): 181-7

8. Ferezin RI, Bertolini DA, Demarchi IG. Prevalence of positive sorology for HIV, hepatitis B, toxoplasmosis and rubella in pregnant women from the northwestern region of the state of Paraná. Rev Bras Ginecol Obstet. 2013; 35 (2): 66-70.

9. Figueiró-Filho EA, Senefonte FR de A, Lopes AHA, Morais OO de, Souza Júnior VG, Maia TL, et al. Prevalência de infecção por HIV, HTLV, VHB e de sífilis e clamídia em gestantes numa unidade de saúde terciária na Amazônia ocidental brasileira. Rev Bras Ginecol Obstet. 2010; 32 (4): 176-83.

10. Bayo P, Ochola E, Oleo C, Mwaka AD. High prevalence of hepatitis B virus infection among pregnant women attending antenatal care: a cross-sectional study in two hospitals in northern Uganda. BMJ Open. 2014; 4 (11): 1-8.

11. Gunardi H, Zaimi LF, Soedjatmiko AR, Muljono DH. Current prevalence of hepatitis $\mathrm{B}$ infection among parturient women in Jakarta, Indonesia. Acta Medica Indones. 2014; (46): 3-9.

12. López-Fabal F, Gómez-Garcés JL. Marcadores serológicos de gestantes españolas e inmigrantes en un área del sur de Madrid durante el periodo 2007-2010. Rev Esp Quimioter. 2013; 26 (2): 108-11.

13. Kupek E, Oliveira JF de. Vertical transmission of HIV, syphilis and hepatitis B in the municipality with the highest incidence of AIDS in Brazil: a population-based study from 2002 to 2007. Rev Bras Epidemiol. 2012; 15 (3): 478-87.

14. Silva R do SU, Ribeiro SAL, Silveira RP, Freitas M dos S. Avaliação da pré-triagem sorológica para o marcador do vírus da hepatite $\mathrm{B}$ (anti-HBc total) em candidatos à doação de sangue no Estado do Acre, 2002. Rev Soc Bras Med Trop. 2006; 39 (2): 179-82. 
15. Fernandes $\mathrm{CN}$ da S, Alves M de M, Souza ML de, Machado GA, Couto G, Evangelista RA. Prevalence of hepatitis B and $\mathrm{C}$ seropositivity in pregnant women. Rev Esc Enferm USP. 2014; 48 (1): 89-96

16. Guedes TG, Moura ERF, de Paula AN, de Oliveira NC, Vieira RP. Mulheres Monogâmicas e suas Percepções quanto à vulnerabilidade a DST/HIV/AIDS. DST-J Bras Doenças Sex Transm. 2009; 21 (3): 118-23.

17. Mehta KD, Antala S, Mistry M, Goswami Y. Seropositivity of hepatitis B, hepatitis C, syphilis, and HIV in antenatal women in India. J Infect Dev Ctries. 2015; 7 (11): 832-7.

18. Amaral TLM, do Prado PR, Monteiro GTR, Ribeiro TS Mendonça DP. Hepatite B e C na gestação: características maternas e neonatais. Rev Interdiscip. 2015; 8 (3): 143-50.

19. Secretaria de Vigilância em Saúde. Nota Técnica Conjunta no 02/2013. 2013.

20. Brasil. Ministério da Saúde. Secretaria de Vigilância em Saúde. Departamento de Vigilância Epidemiológica. Hepatites virais: o Brasil está atento. 3 ed. Brasília, DF; 2008
21. Kiesslich D, Abrahim Fraiji N, Alfaia Crispim M, Ramos Pereira F, Martinho AC, Cordeiro Campello S, et al. Prevalência de marcadores sorológicos e moleculares do vírus da hepatite B em gestantes do Estado do Amazonas, Brasil. Epidemiol Serv Saúde. 2003; 12 (3): 155-64.

22. Souza MT, de Pinho TLR, Santos MDC, dos Santos A, Monteiro VL, Fonseca LMB, et al. Prevalence of hepatitis $\mathrm{B}$ among pregnant women assisted at the public maternity hospitals of São Luís, Maranhão, Brazil. Braz J Infect Dis. 2012; 16 (6): 517-20.

23. Dombrowski JG, Ataíde R, Marchesini P, Souza RM, Marinho CRF. Effectiveness of the Live Births Information System in the Far-Western Brazilian Amazon. Ciênc Saúde Coletiva. 2015: 20 (4): 1245-54.

Received on March 8, 2018

Final version presented on August 20, 2018

Approved on September 28, 2018 